\title{
BAHASA ARAB MODERN DAN KONTEMPORER; KONTINUITAS DAN PERUBAHAN
}

\author{
Abd Aziz \\ STIT Al-Amin Kreo Tangerang \\ azizindunisi@gmail.com \\ Yuan Martina Dinata \\ Pengawas Madrasah Kementerian Agama Kota Bekasi \\ yuan.martina@gmail.com
}

\begin{abstract}
Modern Arabic has a distinction from classical Arabic in terms of lexical, phonological, morphological and syntactic. According to Abbâs al-Sûsah in Muhbib Abdul Wahab, Contemporary Arabic has the following characteristics: 1) accuracy of the use of Arabic at all levels: sound, morphology, syntax, and semantics; 2) more widely used in written language (al-Lughah al maktûbah) than oral language, 3) fluency and diversity-free 'amiyah, 4) standard language that is officially prepared. Based on observations of writers who try to classify modern Arabic vocabulary, the fields of religion, language and literature are the fields with the least development of modern Arabic vocabulary, when compared to economic, political, legal, psychological, health and other vocabularies. This may be due to the fact that from the fields of religion, language and literature there are not many new vocabulary terms, this may be due to religious, linguistic and literary norms.
\end{abstract}

Keywords: Modern Arabic, al-'Arabiyyah al-fushha al-hadith, al-'Arabiyyah al-fushha almu'âshirah

\begin{abstract}
ABSTRAK
Bahasa Arab modern memiliki perbedaan dengan Bahasa Arab klasik dari segi leksikal, fonologi, morfologi dan sintaksis. Menurut Abbâs al-Sûsah dalam Muhbib Abdul Wahab, Bahasa Arab Kontemporer memiliki karakteristik antara lain: 1) akurasi penggunaan Bahasa Arab pada semua level: bunyi, morfologi, sintaksis, dan semantik; 2) lebih banyak digunakan pada bahasa tulis (al-Lughah al maktûbah) daripada bahasa lisan, 3) kefasihan dan bebas ragam 'âmiyyah, 4) bahasa standar yang disiapkan secara resmi. Berdasarkan hasil pengamatan penulis yang mencoba mengklasifikasi kosa kata bahasa Arab modern, bidang agama, bahasa dan sastra adalah bidang yang paling sedikit perkembangan kosakata bahasa Arab modernnya, jika dibandingkan dengan kosakata ekonomi, politik, hukum, psikologi, kesehatan dan lainnya. Hal ini mungkin dikarenakan dari bidang agama, bahasa dan sastra memang tidak muncul banyak istilah kosakata baru, hal ini mungkin dikarenakan kaidahkaidah agama, bahasa dan sastra sudah bersifat baku.
\end{abstract}

Kata kunci: Bahasa Arab Modern, al-'Arabiyyah al fushha al-haditsah, al-'Arabiyyah alfushha al-mu'âshirah.

\section{A. PENDAHULUAN}

Sejak diturunkannya Al- Qur'an dalam Bahasa Arab, Bahasa Arab telah menyebut dirinya sebagai bahasa yang berkembang secara dinamis. Di antara bukti dinamisnya Bahasa Arab adalah semula Bahasa Arab hanya digunakan sebagai alat komunikasi bangsa Hijaz (Arab 
Saudi sekarang). Namun setelah Islam berkembang di kawasan Timur Tengah dan Afrika, banyak bangsa dan negara yang sebelumnya tidak mengenal Bahasa Arab, kemudian bersentuhan dan menggunakan Bahasa Arab sebagai bahasa negara. ${ }^{1}$

Pada masa Abbasiyyah, ketika dimulai peradaban Islam, bahasa Arab telah menjadi bahasa negara. Bahasa Arab telah digunakan lebih dari dua ratus juta pemakai di seluruh duni, terutama di negara Timur Tengah dan negara-negara Afrika Utara dan Barat. Selain itu bahasa Arab telah digunakan sebagai bahasa resmi dunia Islam, setidaknya dalam Organisasi Konferensi atau kerjasama Islam $(\mathrm{OKI})^{2}$.

Bahasa Arab menjadi bahasa peradaban, khususnya dengan banyaknya buku yang diterjemahkan dari bahasa Arab Yunani dan Perancis. Dengan bahasa Arab pula para ulama menulis buku dalam bidang kedokteran, arsitektur, dan matematika serta ilmu-ilmu dari disiplin ilmu yang lain. Bahasa Arab merupakan pioner (pendahulu) bagi ilmu-ilmu Eropa terdahulu yang menjadi dasar bagi peradaban Eropa modern. Pada masa Abbasiyah, masyarakat kota Arab sudah berasimilasi dengan orang-orang awam dan berbaur dengan cara bekerja di lapangan seperti perindustrian, pertanian, dan pekerjaan-pekerjaan lain.

Setelah masa keemasan itu berlalu, bangsa Arab mulai mengalami kemunduran, mereka menjauh dari agama mereka, meninggalkan bahasa Arab baku dan beralih pada dialek. Kemudian muncullah masa penjajahan. Di masa ini penjajah menggerus kebudayaan Islam dan penggunaan tata bahasa Arab baku. Mereka bersungguh-sungguh menanamkan penggunaan beragam dialek Mesir, Maghrib, (Afrika Utara) dan Suriah. Inilah realita yang terjadi, itulah sebabnya terpecahnya bangsa Arab serta menjauhnya mereka satu sama lain. Komunikasi tidak bisa berjalan lancar antara kedua belah pihak, kecuali jika digunakan Bahasa Arab Baku. ${ }^{3}$

Akhir-akhir ini Bahasa Arab menjadi bahasa yang cukup besar peminatnya di Barat. Di Amerika misalnya hampir tidak ada universitas yang tidak memasukkan Bahasa Arab sebagai salah satu mata kuliah. Termasuk Perguruan Tinggi Katolik dan Kristen, tentu dengan maksud dan tujuan tertentu mempelajari Bahasa Arab. Sebagai contoh Harvard University, universitas paling terkemuka di dunia didirikan oleh para petinggi dan pemuka Protestan. Demikian pula Georgetown University, sebuah universitas swasta Katolik, keduanya mempunyai pusat Studi Arab yang kurang lebih merupakan Center for Contemporary Arab Studies.

Sebagai kawasan bisnis yang baru yang sangat terbuka serta menjanjikan peluang serta prospek yang cerah. Timur Tengah adalah primadona baru yang sedang menjadi pusat perhatian banyak kalangan di dunia. Ditandai pula dengan semakin banyaknya lembaga dan perusahaan dari luar Arab berdatangan dan membuka kantor di negara-negara Timur Tengah. Mereka yang berdatangan itu menyadari pentingnya menguasai bahasa Arab selain bahasa Inggris, adalah syarat utama komunikasi dan diplomasi sekaligus pendekatan dengan masyarakat dan negara Tmur Tengah.

Berbagai negara, termasuk Indonesia juga menyadari pentingnya kawasan Timur Tengah sebagai mitra setelah menyadari peluang dan harapan akan masuknya investasi dari negara-negara Arab ke negara mereka. Di Indonesia sudah ada beberapa perwakilan

1 Muhbib Abdul Wahab, Formulasi Konsep Tenses dalam Bahasa Arab Kontemporer (Analisis Linguistik terhadap Pemikiran Tammam Hassân)

2 Dahne Stephan, “ Qur'anic Wording in Political Speeches in Classical Arabic Literature”, Journal of Qur'anic Studies, Vol.3, No.2, 2001,1-13, dalam Adit Tiawaldi dan Muhbib Abdul Wahab, Perkembangan Bahasa Arab Modern dalam perspektif sintaksis dan semantik pada Majalah al Jazeera, Arabiyât, Jurnal Pendidikan Bahasa Arab dan Kebahasaaraban, Vol. 4 No.1 2017.h.2

${ }^{3}$ Amin Nasir, Bahasa Arab Era Klasik dan Modern (Tinjauan Pembelajaran Teoritis), Arabiya Vol. 6 No.1 Januari - Juni 2014. h.22. 
perusahaan dan lembaga keuangan asing yang membuka kantor di Indonesia. Hal ini tidak terlepas dari upaya pemerintah Indonesia peran aktif dan keseriusan pemerintah RI untuk mengundang investor asal Timur Tengah datang ke Indonesia.

Dalam hal ini, proses komunikasi, diplomasi dan negosiasi bilateral tentulah membutuhkan Bahasa Arab sebagai medianya yang paling utama. Sayangnya, harus diakui bahwa tenaga-tenaga ahli yang menguasai bahasa Arab, seperti diplomat dan sebagainya, masih sedikit jumlahnya. Padahal kebutuhan akan hal itu sangat tinggi. Hal tersebut sekaligus menjadi peluang dan tantangan bagi masayarakat Indonesia untuk melihat situasi yang sudah berubah, hubungan Indonesia dengan kawasan Timur Tengah yang semakin intensif dan semakin terbukanya peluang kerja dan berpikir ulang bahwa Bahasa Arab bukan lagi bahasa asing kelas ketiga, tapi sudah menjadi bahasa yang penting dan mutlak perlu dipelajari. ${ }^{4}$

\section{Bahasa Arab Era Klasik}

Menurut ahli Bahasa, bersatunya Bahasa Arab adalah hasil percampuran bahasa pendudukpenduduk yang mendiami semenanjung Jazirah Arab. Tidak diketahui pasti kapan bahasa itu terbentuk seperti sekarang ini dan juga tidak diketahui sebab-sebab yang membawa percampuran bahasa dari penduduk tersebut. ${ }^{5}$

Sejarah sastra Arab merupakan aspek yang cukup penting dalam mengungkapkan perjalanan sastra arab dari zama kuno hingga sekarang. Sejarah sastra arab secara garis besar dibagi ke dalam enam periode:

a. Periode Jahiliyah

Periode ini merupakan periode pembentukan dasar-dasar bahasa Arab. pada masa ini ada kegiatan-kegiatan yang membantu perkembangan bahasa Arab, yakni kegiatan di Pasar Ukaz, Zu al Majaz dan Majannah yang merupakan festival dan lomba Bahasa Arab antara suku Quraisy dan suku-suku lain yang dating ke Mekkah.

b. Periode permulaan Islam

Sejak datangnya Islam sampai berdirinya Bani Umayah, wilayah Islam bertambah luas.mereka menetap dan tinggal di tengah-tengah penduduk asli, sehingga terjadi asimilasi dan pembauran yang memperkuat kedudukan Bahasa Arab. Sastra pada permulaan Islam ditandai dengan turunnya AL Qur'an al Karim melalui perantaarn Nabi Muhammad saw. Dengan landasan AL Qur'an tersebut memotivasi untuk memajukan peradaban dan menebar benih-benih kebaikan, termausk lebih mendalami ilmu pengetahuan dari berbagai cabang ilmu, termasuk ilmu bahasa yang mempelajari kesusastraan.

c. Periode Bani Umayah

Periode ini merupakan periode yang paling gencar sastra syairnya. Pada masa bani Umayah terdapat banyak golongan yang muncul dalam Islam di antaranya Syiah dan Khowarij dan pengikut Abdullah bin Zubair. Keadaan ini menyebabkan posisi syair justru menjadi penyambung lidah sesuai dengan tujuan dari masing-masing golongan Islam tersebut.

d. Periode Abbasiyah

Kehidupan di masa pemerintahan Abbasiyah lebih makmur dna maju, ilmu pengetahuan Islam banyak digali di zaman ini. Pada masa ini masyarakat kota Arab sudah berasimilasi dengan orang-orang awam dan berbaur dengan cara mereka di lapangan seperti perindustrian, pertanian dan pekerjaan-pkerjaan lain yang beraneka ragam. Mereka

${ }^{4}$ Amin Nasir, Bahasa Arab Era Klasik dan Modern (Tinjauan Pembelajaran Teoritis), Arabiya Vol. 6 No.1 Januari - Juni 2014. h.23.

\footnotetext{
${ }^{5}$ Amin Nasir, Bahasa Arab Era Klasik dan Modern (Tinjauan Pembelajaran Teoritis), .......30.
} 
berkecimpung dalam peradaban dan kemodernan. Pada masa ini muncul istilah arabisasi, menggali hukum syariat Islam dari kitab suci Al Qur'an dan menyusun ilmu Bahasa Arab khususnya al Qur'an. Adapuntujuan penggalian bahasa pada masa Abbasiyah adalah:

1. Penyusunan ilmu-ilmu syariat,(ilmu fikih, Aqidah, Balaghah, Ushul Fikih, Nahwu dan Sharaf)

2. Penerjemahan buku-buku bahasa Asing ke dalam bahasa Arab, khususnya ilmu yang berasal dari Yunani kuno

3. Sector industry sebagai buah dari kemajuan peradaban dalam bidang sains dan teknologi

4. Mulai menjamurnya kegiatan ilmiah seperti seminar, diskusi dan pengajaran ilmuilmu pengetahuan.

e. Periode Era Modern

Akhir abad XVIII, ketika bangsa Arab di bawah pemerintahan Daulat Usmaniyah keadaannya sangat lemah. Bangsa Eropa dating ekspansi ke Timur Tengah, tidak dengan kekerasan tetapi kedatangannya dengan dalih untuk menyebarkan ilmu pengetahuan dan berdagang. Pemerintahan berikutnya jatuh ke tangan Muhammad Ali (yang semula diangkat Pemerintah Usmani sebagai gubernur Mesir) berusaha menerima kebudayan barat danilmu pengetahuannya, maka perkembangan sastra berkurang. Baru dua abad kemudian muncullah karya sastra baru dan para penyair menyesuaikan diri dengan zaman modern. Mulai melepaskan diri dari ciri klasik namun masih ada keterikatan. Keistimewaan syair modern ini lebih mementingkan isi daripada sampiran, bahasanya mudah dan sesuai dengan keadaan.

\section{B. TERMINOLOGI BAHASA ARAB MODERN DAN KONTEMPORER}

Bahasa Arab terdiri atas dua ragam, yaitu bahasa Arab klasik dan bahasa Arab modern ${ }^{6}$. Istilah Bahasa Arab kontemporer (اللغة العربية المعاصرة) adalah istilah untuk Bahasa Arab fushha (resmi dan standar) yang digunakan pada masa sekarang, baik untuk penulisan literatur, jurnal, surat kabar, maupun dalam percakapan dan forum resmi, serta tetap menggunakan kaedah baku bahasa Arab.

Sami Boudelaa dan William D Marslen-Wilson dalam Adit Tiawaldi dan Muhbib Abdul Wahab ${ }^{7}$ menyebutkan bahasa Arab modern adalah bahasa Arab yang banyak ditemukan pada media elektronik maupun media cetak, seperti televisi, radio, majalah, koran, dan buku kontemporer Arab. Istilah lain bagi Bahasa Arab kontemporer adalah al-fushha al mu'âshirah, fushha al-'Ashr, Al-'Arabiyyah al-mu'âshirah, al-'Arabiyyah al fushha al-haditsah dan al'Arabiyyah al-fushha al-mu'âshirah.

Bahasa Arab klasik dapat ditemukan dalam Al-Qur'an-meskipun bahasa Arab dalam al-Qur'an selalu aktual dan konstekstual-sebagai rujukan bahasa Arab fushha, dalam hadits,

${ }^{6}$ Ghania Droua Hamdani and Others, "Speaker Independent as For Modern Standard Arabic: Effect of Regional Accents," International Journal of Speech technology, Vol 15 (2012),487-493 dalam Adit Tiawaldi dan Muhbib Abdul Wahab, Perkembangan Bahasa Arab Modern dalam perspektif sintaksis dan semantik pada Majalah al Jazeera, Arabiyât, Jurnal Pendidikan Bahasa Arab dan Kebahasaaraban, Vol. 4 No.1 2017.h.2.

${ }^{7}$ Sami Boudelaa dan William D Marslen-Wilson, "Aralex: A Lexical Database For Modern Standard Arabic,” Behavior Research Methods, Vol.42,No2, 2010, 481-487, dalam Adit Tiawaldi dan Muhbib Abdul Wahab, Perkembangan Bahasa Arab Modern dalam perspektif sintaksis dan semantik pada Majalah al Jazeera, Arabiyât, Jurnal Pendidikan Bahasa Arab dan Kebahasaaraban, Vol. 4 No.1 2017.h. 2 
dan buku-buku klasik dan abad pertengahan. ${ }^{8}$ Bahasa Arab klasik sudah ada sebelum Islam, sejak masa Jahiliyah, sejak sebelum abad ke- $6 .{ }^{9}$

Secara empirik dan teoritik, bahasa Arab tidak berbeda jauh dengan bahasa lainnya, dapat berkembang sesuai kepentingan para penuturnya, karena suatu bahasa akan hidup jika masyarakat masih menggunakannya dan bahasa tersebut akan mati jika terjadi sebaliknya (sudah tidak digunakan lagi).

Bahasa Arab modern dan kontemporer sama dengan bahasa Arab klasik, baik dalam bahasa lisan maupun bahasa tertulis. Perbedaannya hanya terletak pada perkembangan dan perbendaharaan kosa kata (mufrodat), di mana pada Bahasa Arab modern dan kontemporer perkembangan bahasanya mengikuti perkembangan kata yang mengiringi perkembangan zaman, sedangkan bahasa Arab klasik mengacu pada adat kebiasaan lama demikian pula bahasa Arab modern lebih sering digunakan dalam penyampaian berita dan penulisan berita. ${ }^{10}$

\section{PEMBAHASAN}

\section{Penelitian Terkait Bahasa Arab Modern}

Muhbib Abdul Wahab telah melakukan penelitian tentang formulasi tenses dalam Bahasa Arab kontemporer melalui analisis linguistik terhadap pemikiran nahwu Tammam Hassan. Berdasarkan temuan dan analisisnya terhadap pemikiran nahwu Tammam Hassan, disimpulkan sebagai berikut: pertama, formulasi konsep tenses dalam pemikiran Tammam Hassan dilandasi kerangka teori yang melihat Bahasa Arab sebagai sebuah sistem bahasa yang elastis dan kaya ragam ungkapan. Tenses dalam Bahasa Arab kontemporer tidak dipengaruhi oleh konsep serupa dalam Bahasa Inggris, karena penggunaan tenses dalam Bahasa Arab memiliki akar historis dan bukti faktual dalam berbagai khazanah intelektual Arab klasik maupun kontemporer, terutama teori ta'liq dan al nazham yang dicetuskan oleh 'Abd al Qâhir al-Jurjâni.

Kedua, Tammam Hassan memformulasikan konsep tenses dalam bahasa Arab kontemporer dengan tetap mendasarkan pada pembagian konsep waktu (tala) yang melekat pada bentuk fi' $i l$, lalu dihubungkan dengan konsteks dimana fi'il distrukturkan dan dirangkai dengan af'al nasikhah, af'al syurû', af'al muqârabah, dan zharaf zaman serta 'adawat lain yang menyertainya. Formulasi tenses menghasilkan bentuk (binyah) dan makna fungsional dan konstekstual sesuai dengan siyâq al kalâm yang menjadi penyertanya (al qarâin al lafzhiyyah) dan konsteks sosial budaya yang melingkupi pemaknaannya (al qarâin ghair al lafzhiyyah)

Ketiga, pemikiran nahwu Tammam Hassan mengenai penggunaan bahasa kontemporer memberikan implikasi semantik yang sangat penting dan menarik. Implikasi tersebut dapat dijadikan salah satu pendekatan semantik dalam memahami teks khususnya al Qur'an, implikasi tersebut memberinya insprasi untuk menghadirkan keindahan gaya bahasa dan kedalamanan makna al Qur'an dalam karya monumentalnya: al-Bayân fi Rawâi' al Qur'an; Dirasah Lughawiyyah wa Ushlubiyyah li-Nashsh al-Qur'an.

Adit Tiawaldi dan Muhbib Abdul Wahab mengadakan penelitian tentang Perkembangan Bahasa Arab Modern dalam perspektif sintaksis dan semantik pada Majalah al

\footnotetext{
${ }^{8}$ Mohammad A. M. Abu Shariah and Others, "Phonetically Rich and Balanced Text and Speech Corpora," Lang Research \& Evaluation, Vol.46,2012,601-634.

${ }^{9}$ Issa J.Boullata," Midlle East Studies Association of North America (MESA), " Review of Middle East Studies, Vol.48, No.1/2,2014,116-117,http://www.Jstor.Org/Stable/2433136, accesed:21-01-2016,48 UTC

${ }^{10} \mathrm{https}$ ://wirsablog.wordpress.com/2012/09/15/bahasa-arab-modern-2/ Diakses 23 Maret 2018. Pukul 14.30 WIB.
} 
Jazeera. ${ }^{11}$ Objek penelitian ini adalah majalah daring al Jazeera dalam bentuk analisis makna leksikal, gramatikal dan kontekstual dan penelitian analisis frasa, klausa dan verbal. Penelitian ini menggunakan teori al-Nazhariyyah al-Siyaqiyyah atau teori konstektual yang dikembangkan oleh J.R. Firth. Penelitian ini mengungkapkan bahwa Bahasa Arab modern yang digunakan oleh Majalah Online al Jazeera telah mengalami perkembangan dalam makna dan struktur. Perkembangan ilmu pengetahuan (sains) dan teknologi mempengaruhi pada perkembangan kosa kata bahasa Arab pada bidangnya masing-masing seperti politik, ekonomi, ilmu pengetahuan dan teknologi.

\section{Karakteristik Bahasa Arab Modern}

Bahasa sebagai salah satu gejala sosial masyarakat yang digunakan untuk berkomunikasi sesama manusia. Maka sebagai gejala komunikatif, perlu dibedakan pengggunaan dan fungsi dari bahasa tersebut. ${ }^{12}$ Fungsi bahasa dalam masyarakat berhubungan dengan pemakaian dengan bidang kehidupan yang khas, artinya di luar bidang itu bahasa digunakan secara umum. Bidang pertama untuk Bahasa Arab adalah bidang agama dan ibadah, merupakan contoh Bahasa Arab klasik sebagai bahasa umat Islam. ${ }^{13}$ Karena itu di sana Bahasa Arab berfungsi sebagai bahasa agama dan ibadah. Dalam fungsinya sebagai sarana dalam kitab suci akan memberikan dampak, bahasa Arab itu sering dijadikan objek studi dalam berbagai bidang pendidikan yang bercorak keagamaan seperti institut agama, sekolah teologi dan seminar-seminar. ${ }^{14}$

Bahasa Arab modern diidentifikasi sebagai bahasa tertulis yang digunakan sebagai bahasa media. Hal ini menjadi perhatian para ahli bahasa dalam beberapa tahun terakhir karena stabilitasnya, karena kegunaannya serta kemampuanyya sebagai sebuah model penggunaan penulisan. Bahasa sebagai bentuk tertulis (broadcast) maupun sebagai bahasa standar media berita telah menjadi sebuah fenomena yang biasa terjadi, terutama dalam masyarakat multi bahasa, diglossia ${ }^{15}$ dan multi dialek. Bahasa Arab, menurut Vincent Monteil, secara fungsional merupakan bahasa media berta Arab, dan merupakan bahasa resmi. Bahasa Arab modern dikodifikasikan sebagai fenomena yang terpisah dari Bahasa Arab klasik, karena orang Arab dan ahli bahasa mempunyai opini yang obyektif tentang apa yang disebut sebagai Lahjat alJarâid. Menurut Badawi, fushhâ adalah istilah Bahasa Arab untuk bahasa Arab modern dan bahasa komunikasi formal baik dalam bentuk lisan maupun tulisan.

${ }^{11}$ Adit Tiawaldi dan Muhbib Abdul Wahab, Perkembangan Bahasa Arab Modern dalam Perspektif Sintaksis dan Semantik pada Majalah al Jazeera, Arabiyât, Jurnal Pendidikan Bahasa Arab dan Kebahasaaraban , Vol. 4 No.1 2017.h. 1-19.

12 J.D. Parera, Teori Semantik (Jakarta: Erlangga, 2004), 11.

${ }^{13}$ Christian Julien Robin, "The Development of Arabic As A Writeten Introduction Language Types", Proceedings of The Seminar For Arabian of Arabic As A Written Language". Papers From The Special Session of The Seminar For Arabian Studies Hold on 24 July (2010),p1-3 Published by: Archaeopress Stable URL: htt://www.Jstor.Org/Stable/41224040.

14 Anton M. Moeliono, Perkembangan dan Pembinaan Bahasa: Rancagan dan Alternatif di dalam Perencaan Bahasa (Jakarta: Djambatan,1985),50.

${ }^{15}$ Situasi diglosia adalah suatu komunitas bahasa yang memiliki dua vaiasi bahasa yang berbeda dalam hal tujuan Variasi pertama adalah bahasa arab klasik yang digunakan dalam kehidupan sehari-haridan merupakan bahasa Ibu dari seian banya dialek di kawasan negaraArab Variasi kedua adalah bahasa Arab modern atau dikenal dengan bahasa formal, yang digunakan sebagai bahasa pendidikan dan bahasa media baik lisan maupun tulisan. 
Bahasa Arab modern memiliki perbedaan dengan Bahasa Arab klasik dari segi leksikal, fonologi, morfologi dan sintaksis ${ }^{16}$. Menurut Abbâs al-Sûsah dalam Muhbib Abdul Wahab ${ }^{17}$, Bahasa Arab Kontemporer memiliki karakteristik antara lain: 1) akurasi penggunaan Bahasa Arab pada semua level: bunyi, morfologi, sintaksis, dan semantik; 2) lebih banyak digunakan pada bahasa tulis (al-Lughah al maktûbah) daripada bahasa lisan, 3) kefasihan dan bebas ragam 'amiyyah, 4) bahasa standar yang disiapkan secara resmi.

\section{Perkembangan Bahasa Arab Modern}

Meskipun interaksi antara budaya Arab dan Barat telah berlangsung lama, namun interaksi yang membawa pengaruh besar bagi perkembangan budaya Arab bermula saat kedatangan Napoleon ke Mesir pada tahun $1798^{18}$. Sejalan dengan pendapat Adit Tiawaldi dan Muhbib Abdul Wahab, modernisasi (tahdits) Bahasa Arab yang dimulai di Mesir dan Suriah sejak abad ke-19, banyak dipengaruhi asing di bidang intelektual, sosial dan perkembangan politik di wilayah Timur Tengah. Modernisasi itu dimulai sejak ekspedisi Napoleon ke Mesir pada akhir abad ke-19. Pada masa ekspedisi tersebut Napoleon memberi banyak kontribusi dengan mengenalkan percetakan surat kabar untuk pertama kalinya di Mesir, menterjemahkan literatur Barat ke dalam Bahasa Arab. ${ }^{19}$ Pada saat itu para pakar bahasa Arab, ulama, sastrawan,para jurnalis ikut serta dalam proses modernisasi bahasa. Ketika itu didirikanlah majma' al Lughah al-'Arabiyyah di Kairo yang berperan dalam modernisasi yang dilakukan untuk menjaga keseimbangan bahasa Arab fushhâ dan merupakan indikasi terhadap perkembangan zaman. ${ }^{20}$

Kontak budaya Arab dengan budaya Eropa tersebut dilanjutkan pada masa Mohammad Ali, banyak putra Mesir yang dikirim ke Eropa untuk belajar agar mereka bisa mengajarkan ilmu mereka setelah kembali ke Mesir. Modernisasi Bahasa Arab juga banyak dipengaruhi oleh imigran Arab di Amerika dan dari miisionary yang membawa pendidikan Barat ke berbagai wilayah timur Tengah. Kontribusi imigran itu berupa penerjemahan keilmuan Barat ke dalam Bahasa Arab yangbanyak dipengaruhi bahasa Inggris dan Perancis. Keilmuan yang mereka ajarkan adalah kedokteran, dan sains. Pada masa itu ada dua institusi yang berpengaruh dalam melahirkan para inteletual Arab yaitu Universitas Saint Josepth (1873) dan Universitas Amerika di Beirut.

Abad ke -19 dianggap sebagai masa perkembangan linguistik terutama pada linguistik historis komparatif. Pada masa ini orang sudah mulai memikirkan otonomisasi linguistik sebagai sebuah ilmu, khususnya perhatian orang tertuju pada bahasa tertulis.

\section{KESIMPULAN}

Dari uraian di atas dapat difahami bahwa Bahasa Arab merupakan bahasa yang dinamis, bahasa yang hidup dan akan terus berkembang. Hal ini dikarenakan selama sebuah bahasa itu

\footnotetext{
${ }^{16}$ A. Mahfoud And Friends, Introduction To The Special Issue A Literacy In Arabic, “Artice Reading ad Writing, Vol.24, No.9, 2011,1011-1018.

17 Abbâs al-Sûsah, al-'Arabiyyah al-fushha al-Mu'ashirah, (Kairo : Dâr Garîb, 2002) h.14, dalam Muhbib Abdul Wahab, Formulasi Konsep Tenses dalam Bahasa Arab Kontemporer (Analisis Linguistik terhadap Pemikiran Tammam Hassân)

${ }^{18}$ Haywood 1971 dan Andangdjaya 1983,14. Dalam Taufiq A. Dardiri, Perkembangan Puisi Arab Modern (Adabiyat: Vol. X, No. 2 Desember 2011), 288.

19 Adit Tiawaldi dan Muhbib Abdul Wahab, Perkembangan Bahasa Arab Modern dalam Perspektif Sintaksis dan Semantik pada Majalah al Jazeera,....h.3

${ }^{20}$ Muhammad Hasan'Abd al 'Aziz, al-'Arabiyyah al-Mu'âshirah: Qadhâya wa Musykilât (Kairo: Maktanah al-Adab),153-154.
} 
digunakan selama itu pulalah sebuah bahasa akan terus berkembang. Dan sebaliknya manakala bahasa itu tidak digunakan lagi maka bahasa itu akan mati.

Sami Boudelaa dan William D Marslen-Wilson dalam Adit Tiawaldi dan Muhbib Abdul Wahab ${ }^{21}$ menyebutkan bahasa Arab modern adalah bahasa Arab yang banyak ditemukan pada media elektronik maupun media cetak, seperti televisi, radio, majalah, koran, dan buku kontemporer Arab. Istilah lain bagi Bahasa Arab kontemporer adalah al-fushha al mu'âshirah, fushha al-'Ashr, Al-'Arabiyyah al-mu'âshirah, al-'Arabiyyah al fushha al-haditsah dan al'Arabiyyah al-fushha al-mu'âshirah.

Bahasa Arab modern sebagai bahasa resmi dan standar di media, baik media cetak maupun media elektronik, baik bahasa tulisan maupun bahasa tulisan akan terus berkembang sejalan dengan perkembangan ilmu pengetahuan dan teknologi dan dalam semua bidang seperti ekonomi, politik budaya dan lain sebagainya. Berikut ini diuraikan contoh-contoh bahasa Arab modern /kontemporer. Setelah penulis mencoba mengklasifikasi bahasa Arab modern yang sudah banyak digunakan, penulis mengambil kesimpulan bahwa untuk bidang politik dan ekonomi termasuk bidang yang paling banyak muncul bahasa arab modernnya .sedangkan bidang agama dan bahasa dan sastra merupakan bidang yang paling sedikit muncul bahasa modern/kontemporernya.

\section{CONTOH KOSA KATA BAHASA ARAB MODERN DAN KONTEMPORER}

\section{BIDANG EKONOMI DAN PERINDUSTRIAN}

\begin{tabular}{|c|c|}
\hline Investasi & إِسْتِتمَمَارُ \\
\hline Produksi & إنتَّاج \\
\hline Monopoli & إِحتِكِارُ \\
\hline Administrasi bisnis & إدَارَة العَمَل \\
\hline Import & إنستِيْرَاد \\
\hline Asset perusahaan & أُصُوْلُ الشرِّركة \\
\hline Bangkrut & إِقلاًَ \\
\hline Administrasi perusahaan & إعَارَة الشُرِكَّة \\
\hline Juru bayar & 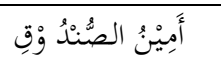 \\
\hline Eksport & تَصْدِ يْر \\
\hline Titipan barang & إِيْدَ اعُ الْبضضَاعَة \\
\hline Asuransi & تأَِْْيْن \\
\hline Biaya dasar, biaya awal & التُكَكلُُعَة الْمَبْدَ بِيَيَة \\
\hline Kekayaan & تَرْوَة / ترَاءُ \\
\hline Bank sentral & بَنْنُ الحمَركزَ \\
\hline Analisa & تَحْحِيْيل \\
\hline Modal, Kapital & رَأُسُ مَالِيُّ \\
\hline Modal usaha & رَأْسُ مَالِ الْمَسَاعِي \\
\hline
\end{tabular}

${ }^{21}$ Sami Boudelaa dan William D Marslen-Wilson, "Aralex: A Lexical Database For Modern Standard Arabic,” Behavior Research Methods, Vol.42,No2, 2010, 481-487, dalam Adit Tiawaldi dan Muhbib Abdul Wahab, Perkembangan Bahasa Arab Modern dalam perspektif sintaksis dan semantik pada Majalah al Jazeera, Arabiyât, Jurnal Pendidikan Bahasa Arab dan Kebahasaaraban, Vol. 4 No.1 2017.h. 2 


\begin{tabular}{|c|c|}
\hline Efisiensi anggaran & فَعَّالِيَّة مِيْزَزانِيَة \\
\hline Kebijaksanaan moneter & السِّيَّاسَة النَّندِد يَة \\
\hline Transaksi & صَفْقِة \\
\hline Pelanggan & زَزبوُنْ \\
\hline Obligasi & سَنَدُ \\
\hline Produksi kerajinan tangan & الصُنَاعِيَة اليُدَ وِيَة \\
\hline Pelaku usaha & صَاحِبُ الأَعْمَالِ \\
\hline Usaha produktif & عَمَلُ مُنْنِجِ \\
\hline Uang muka/panjar & عَرَبْبُونْ \\
\hline Audit keuangan & مُرَاجَعَة مَالِيَّة \\
\hline Banker & مَصْرَفِيّ \\
\hline Hasil produksi & 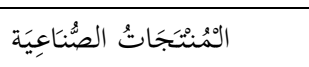 \\
\hline Investor & مُسْتتَّمِرِ \\
\hline Pajak & ضَرِيْبَة ج جَرَائِبْ \\
\hline Konvensional & التََّّمِلِِ يَة \\
\hline Insentif & حَافنٍُ \\
\hline Pertambahan tajam & الزِّيَادَة الحادَة \\
\hline Multi dimensi & 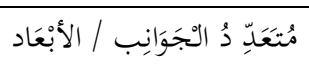 \\
\hline Area perdagangan bebas & مَنْطِقِة التِّجَارَة الوحُحَرَّة \\
\hline Kawasan industry & المَنْطِقِة الصُُنَاعِيَة \\
\hline Air mineral & مَاءُ مَعْدَ نِيْ \\
\hline Agen & وَكِيْنُ , عمِيْلُ \\
\hline Titipan uang & وَدِ يْعَةُ النُعُْوْدِ \\
\hline Akomodasi & وَسَائِلُ الرَّاَحِةِ \\
\hline Temu karya/usaha & لِقَاءُ الْعَمَلِ \\
\hline Tamu hotel & نَزْلَاءُ الفْنَّادِقِق \\
\hline Transportasi & منقِلُْ / مُوَاصَلة \\
\hline Agen distribusi & وَكالة التَّزَِِيْعِ \\
\hline Bahan bakar & 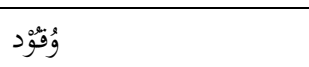 \\
\hline Akomodasi perjalanan & 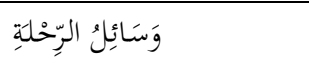 \\
\hline
\end{tabular}

BIDANG SOSIAL, POLITIK DAN KEAMANAN

\begin{tabular}{|c|c|}
\hline Kecaman & 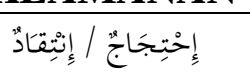 \\
\hline ASEAN & إِتِحَحادُ أمَمِ شرَق آسِيَا \\
\hline Bentrokan & إِشتِنِبكاك \\
\hline Konfrontasi militer & الإشتْْبَباكُ العَسْكِكِيَّة \\
\hline Terorism & إرْهَابِيَة \\
\hline Aksi militer & إِجْرَاءَات عَسْكركِيَة \\
\hline
\end{tabular}




\begin{tabular}{|c|c|}
\hline Interogasi & إِ إِتْتِجْوَابُ \\
\hline Pemilihan umum & إنْتِخَابَات عَامَّة \\
\hline Tahanan politik & أَسِيْرِ سِيَاسِيٌْ \\
\hline Bukti otentik & بُبرهَانٌ قَاطع \\
\hline Sidik jari & بَعْمَة \\
\hline Sabotase & 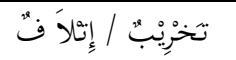 \\
\hline Bukti pengesahan & إنثِّاتُ صِحَّة الُوَصِيَة \\
\hline Pertukaran tawanan & تمبَادُ لُ الأَسْرَاء \\
\hline Revolusi & تَورَرة \\
\hline Sekelompok/segelintir prajurit & حُفْنَة مِنَ العَسْكَر \\
\hline Politisi, Tokoh politik & رِجَالٌ سِيَّاسِي \\
\hline Peta politik & الْخرَيْطَة السِيَّاسِيَة \\
\hline Dialog persahabatan & الْحِوَارُ الحَضَضَارِي \\
\hline Aparat keamanan nasional & مِهَاز الأَمْنِ القَوْمِيّ \\
\hline Pangkat militer & رُرنبَُ عَسْكِكرِية \\
\hline Perampokan bersenjata & 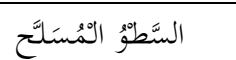 \\
\hline Aksi sabotase & عَمَلِيَّة تثخرِيْبِبَة \\
\hline Politik persoalan di belakang & سِيَاسَة الأمْر الوَاقِع \\
\hline Aksi sabotase & عَعَلِيَّة تَخْرِيْبَِة \\
\hline Tebusan tawanan & فِدَد اءُ الأَسِيِِْ \\
\hline Gas air mata & غَازٌ مُسِيْل الدُمُوْْع \\
\hline Pengamat politik & المُركراقِبُ المِيّناسِي \\
\hline $\begin{array}{l}\text { Sekular lisasï_baik ystem aerah } \\
\text { bagi provinsitensialnye }\end{array}$ & عِلمَانِيُّ \\
\hline Senjata nuklir & قَتُبْلة نوَاوِيّة \\
\hline Fasilitas umum & تَسْْهِيْلاً تُ عَامَّة \\
\hline Decision maker & صَانعُ القْرَار \\
\hline Analis politik & المُحَحلِّهُ الِسِيَّاسِي \\
\hline Jendral & فَرِيْق \\
\hline Letnan jendral & قَرِيْق أوَّل - \\
\hline Nuklir & نَوَوِيُّ \\
\hline Membabi buta & اَشْوَاعِيُُّ \\
\hline Afiliasi & إنْتْمَاء \\
\hline Marsekal & المَشِيْر - \\
\hline Mayor jendral - & 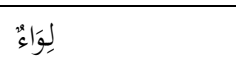 \\
\hline Brigade jendral & عَمِيْد - \\
\hline Kolonel & عَقِقيْد - \\
\hline Letnan colonel & مُعَدَّم م- \\
\hline
\end{tabular}




\begin{tabular}{|c|c|}
\hline Mayor & 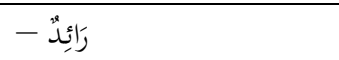 \\
\hline Kapten & ن نِّيْبُ - \\
\hline Letnan satu & مُلالَزْم آَوَّل - \\
\hline Letnan & 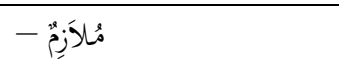 \\
\hline Sersan & رَرقِيْبٌْ - \\
\hline Kopral & عَرَِيقق - \\
\hline Budayawan & شَخْصِيَة ثنقَتَفِيَة \\
\hline Tokoh/Pemuka masyarakat & شَخْْصِيَّاتُ عَامَّة \\
\hline Jaringan & شبْكة \\
\hline Gejala (sosial) & ظلاهِرَة ج ظوَاهِر \\
\hline Anggota peninjau & العَضُوُ المُمَركِبَ \\
\hline Anggota tetap & العَضُضُوُ الدَّ ائِم \\
\hline Anggota kehormatan & 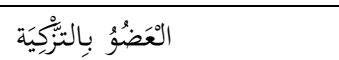 \\
\hline Kolektif/missal & الْجِمَاعِي \\
\hline Komisi khusus pencari fakta & لَجْنَة خَاصَّة لِتِعَصِّ الْحَتَائقَ \\
\hline Pemerhati masalah politik & المُهُهُمَمَّونَ بِالسِيَّاسَة \\
\hline Calon, kandidat & 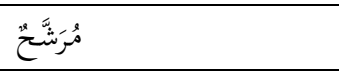 \\
\hline Konfrontasi militer/fisik & 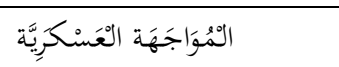 \\
\hline Multilateral & مُمَتَعَِّّدُ الأطرُرافِ \\
\hline Nepotisme & مَحْسْوُوبِيّة \\
\hline Negoisasi & مُفَفَضَة \\
\hline Atase kebudayaan & مُلحَق الثنََّافِي \\
\hline Partisipasi aktif & 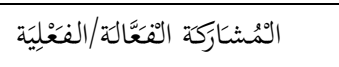 \\
\hline Aktivis politik & نَشِيْطِ سِيَّاسِي \\
\hline Antipati & نُنُوْر \\
\hline Aklamasi & مُمَافَقَة بِاْلندنافِ \\
\hline System multy partai & 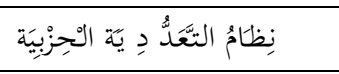 \\
\hline Konsekwensi alami/normal & نَبِيْجَجة طبرِعِيَّة \\
\hline Konsekwensi logis & النَِّيْجَة الْمَنِِْقِيَة \\
\hline Anggaran rumah tangga & نِظِامُ دَاخِلِيّ \\
\hline Demonstrasi & مُظظاهَرَة \\
\hline Arak-arakan, Pawai & مَسِيْرَة جَ مَسِيْرَات \\
\hline Rombongan (mobil) & مَوَكِب \\
\hline Sukarelawan & 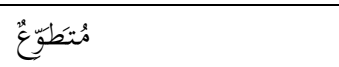 \\
\hline Sindikat & لِقِتَبَة \\
\hline Identitas nasional & الوهِوَايَة الوَطَنَيَّة \\
\hline Anggota tetap/berkeanggotaan tetap & 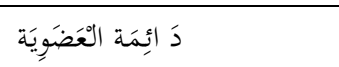 \\
\hline
\end{tabular}




\begin{tabular}{|l|l|}
\hline Asosiasi & نقعَبَّة \\
\hline
\end{tabular}

BIDANG AGAMA

\begin{tabular}{|c|c|}
\hline Zionis & صُحَحُيُونِيُّ \\
\hline Atheis & إلْحَحادِ يَة \\
\hline
\end{tabular}

BIDANG KOMUNIKASI

\begin{tabular}{|c|c|}
\hline Berita utama & أخْبَارُ ريَيِْسيَة \\
\hline Iklan terselubung & الإعْلالَنُ الوُسْنَتِكر \\
\hline Siaran (luar negeri) ke ... & البُرَامِجُ المُوَجَّهَهَة إلَّي \\
\hline Saling mempengaruhi & 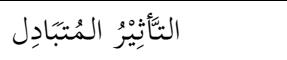 \\
\hline Kampanye & حَمْلَة / دِ عَايَّة \\
\hline Kalangan pers & رِِجالُ الصَّحَافة \\
\hline Waktu siaran & 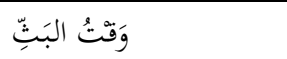 \\
\hline Jalur komunikasi & قنَّاة الإتِصَّال \\
\hline Buah bibir & مِحْوَرُ الْحَدِيْث \\
\hline Loby & جَمَاعَة الضَّغنط \\
\hline Spanduk & لاََفِتَّة \\
\hline Diam seribu bahasa & الصَّمْتُُُ المُطُبْق \\
\hline Media cetak & 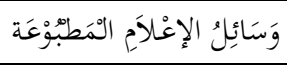 \\
\hline Jumpa pers & لِقَاءٌ صَحَفِيٌّ \\
\hline
\end{tabular}

BIDANG HUKUM DAN TATA NEGARA

\begin{tabular}{|c|c|}
\hline Aparat pemerintah daerah & 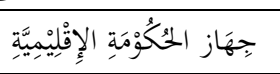 \\
\hline Pelanggaran-pelanggaran & ت تَجَاوَزًَات \\
\hline Kebijaksanaan & 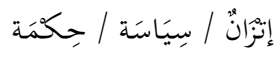 \\
\hline Amandemen undang-undang & 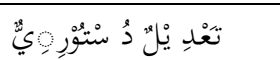 \\
\hline Krisis kredebilitas & 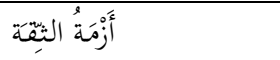 \\
\hline Pengesahan & 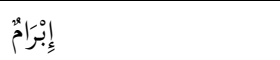 \\
\hline Otonomi & 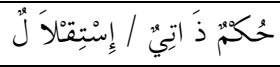 \\
\hline Pejabat Negara & رِِجَالُ الدَّولِّة \\
\hline Sogok, suap & رَشَشْوَة \\
\hline Daftar hitam & قَائيمَة سَوْدَاء \\
\hline Pelecehan & 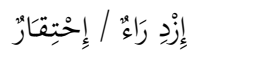 \\
\hline Korban tewas & ضَحِيَّةُ القَتَبِيْلِ \\
\hline Badan amnesty internasional & 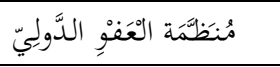 \\
\hline Pelanggaran-pelanggaran & مُخَالفَات \\
\hline APBD & 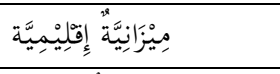 \\
\hline APBN & 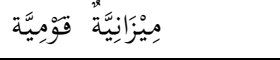 \\
\hline
\end{tabular}




\begin{tabular}{|c|c|}
\hline Pemerintahan peralihan & 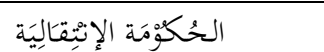 \\
\hline Kesalahan besar/fatal & الْخَطُأ الفُّادِح \\
\hline Pangkat, gelar & 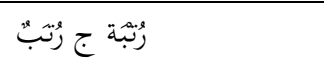 \\
\hline Denda & غرَامَة \\
\hline Saling menuduh & 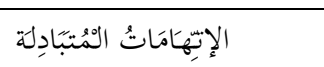 \\
\hline Membebaskan & إخْلاءُ سَبِيْل \\
\hline Nama baik & سُمْنعةُة / شُهُهَرة \\
\hline Komunis & ش شيُوِِْْيّي \\
\hline Auditor & مُرَاجِعُ الْحِسَابَات \\
\hline Auditor eksternal & مُرَاجعُ الْحِسَابَات الْخَارِجِيَة \\
\hline Auditor internal & مُرَاجعُعُ الْحِسَابَات الدَّاخِلِيَّة \\
\hline Tanggung jawab individu & 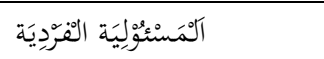 \\
\hline Tanggung jawab sosial & الهَسْئُوْلِيَة الإِجْتِمَاعِيَّة \\
\hline Tanggung jawab semua orang & 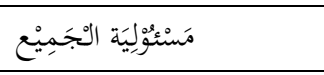 \\
\hline Tanggung jawab utama & 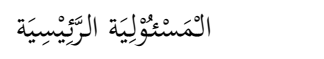 \\
\hline Berita acara perkara & مَحَضْرَ \\
\hline Palsu, imitasi & مُمْزَيَّنُ \\
\hline Narkoba & 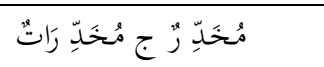 \\
\hline
\end{tabular}

\section{BIDANG PSIKOLOGI}

\begin{tabular}{|c|c|}
\hline Pesimis & تَشَّائُمْ \\
\hline Motif & حَافِنز / بَاعِثُ \\
\hline Saling mencintai & الْحُعبُُ المُتَتبَّادِل \\
\hline Optimis & 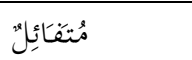 \\
\hline Ambisi & طرمُوُْْ / هِمَّة \\
\hline Positif & إيْجَابي \\
\hline Spontan & 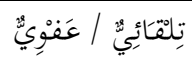 \\
\hline Fase perubahan/pergeseran & مَرْحَلَّة تَحَحوّل \\
\hline Fase peralihan & مَرْحَلة إنتْقِّال \\
\hline Sikap & مَوْقِفْ \\
\hline Tahap, fase & مَرْحَلَة / طورُّ \\
\hline Indikator & 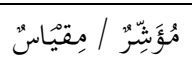 \\
\hline Gaya hidup & نَمْط الْحَيَاة \\
\hline Wibawa & 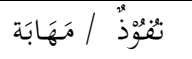 \\
\hline Pesimis & خَيْبَة الأمَل \\
\hline
\end{tabular}

BIDANG MANAJEMEN

Tujuan utama, sasaran inti

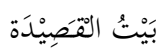




\begin{tabular}{|c|c|}
\hline Evaluasi & تتقيْيَمِ \\
\hline Operasi, Proses & عَمَلِيَّة \\
\hline Struktur, bagan & هَيْكلُ / بُنْيَانُ \\
\hline Tujuan akhir & غَرْضٌ نِهَهَائِيُّ \\
\hline Bermutu tinggi & عَالِيَّة الْجَوْدَة \\
\hline Tujuan utama & غَايَةُ رَرَيِْْسيَّة \\
\hline Batu pertama & الْحَجُرُ الأسَاسِي \\
\hline Agenda kerja & جَحْد وَلُ الأعْمَالِ \\
\hline Rancangan & 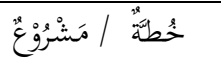 \\
\hline Tanda tangan & 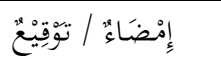 \\
\hline Kesempatan kerja & قرَّصَةُ الأعَعْمَالِ \\
\hline Upaya kolektif & الوُجْهُهُ الْجِمَاعِي \\
\hline Substansi & بَجوْهَرُ \\
\hline Mutu & جَوْدَة \\
\hline Akreditasi & إعْتِمَادُ \\
\hline Arah berlawanan & الإتِّجَاهُ الُْمُعَاكِس \\
\hline Horizontal & أُعْقِيُّ \\
\hline Bermutu tinggi & عَالِيَّة الْجَوْدَة \\
\hline Unsur & عُنْصُرُ \\
\hline Tata cara & كيَفِيَيَةُ العَعَمَلِ \\
\hline Panitia & لَجْْنة \\
\hline Panitia ad hoc & لَجْنَة خَاصَّة \\
\hline Anggaran dasar & قانوُونُ أسَاسِيّ \\
\hline Konfrension hall & قَاعَة المُوُْْتَمَرَات \\
\hline Balai pertemuan & قَاعَة إِجْتِمَاعِيِّة \\
\hline Kertas kerja & وَرَقَة الأعْمَالِ \\
\hline Situasi kondisi & وَضْعُعُ ج أوْوضَاعُ \\
\hline Akses & 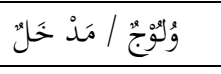 \\
\hline Tujuan strategis & 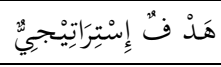 \\
\hline
\end{tabular}

KESEHATAN

\begin{tabular}{|c|c|}
\hline Hilang ingatan, amnesia & فِقعْدَ انُ الذَّ اكِكرة \\
\hline Sendi-sendi & رَكِيْزة ج رَكَائزْ \\
\hline Gejala (penyakit) & عَرْضٌ جَ اَعَرَاض \\
\hline Pentilasi & مَجْرَى الْهَوَاء \\
\hline Hilang nafsu makan & 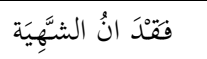 \\
\hline Panca Indra & الَْحَاسُ الْخَمْس \\
\hline Pendengaran & السَّمْعُ \\
\hline
\end{tabular}




\begin{tabular}{|c|c|}
\hline Penglihatan & البُصَرُ \\
\hline Perasa & التََّّ وُوقق \\
\hline Penciuman & الشَّمَ \\
\hline Pasien rumah sakit & نَزْلاَُ المُستتَشَفْفِيَات \\
\hline
\end{tabular}

\section{BAHASA DAN SASTRA}

\begin{tabular}{|c|c|}
\hline Resensi buku & عَرْضُ الْكِتَابِ \\
\hline Dewan redaksi & مَجْلِسِسُ التَََّْرِيْر \\
\hline Pameran buku & مَعْرَضُ الكِكِتَابِ \\
\hline
\end{tabular}

\section{TEKNIK/ ARSITEKTUR/ PERTAMBANGAN}

\begin{tabular}{|c|c|}
\hline Beton & الأسنْمِنْتَ المُسُسَلَّح \\
\hline Baja & قِوَلاًذ \\
\hline Gangguan teknis & 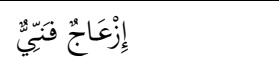 \\
\hline Cat scanner & جَهَازُ الأشَعَعَة الوُعُعْطِعِيَة \\
\hline
\end{tabular}

\section{GEOGRAFI}

\begin{tabular}{|c|c|}
\hline Banjir & فيَضِضَان \\
\hline Pelangi & قُؤسُ قُّح \\
\hline Astronot & رَائيدُ الفْضَضَاء \\
\hline Merehabilitasi & إِعَادَة الإعَتْبَبَارِ \\
\hline Bencana & كَارِتة / مادِ حَة \\
\hline Bencana alam & كرَتَّة طبعِيَة \\
\hline Tumpukan & كَوْمَة / كُدْ سُ \\
\hline Badai & عَاصِفة \\
\hline Argometer & العَدَاد \\
\hline
\end{tabular}




\section{DAFTAR PUSTAKA}

'Abd al 'Aziz, Muhammad Hasan. al-'Arabiyyah al-Mu'âshirah: Qadhâya wa Musykilât (Kairo: Maktanah al-Adab), 153-154.

Abdul Wahab, Muhbib. Formulasi Konsep Tenses dalam Bahasa Arab Kontemporer (Analisis Linguistik terhadap Pemikiran Tammam Hassân)

Adit Tiawaldi dan Muhbib Abdul Wahab, Perkembangan Bahasa Arab Modern dalam Perspektif Sintaksis dan semantik pada Majalah al Jazeera, Arabiyât, Jurnal Pendidikan Bahasa Arab dan Kebahasaaraban, Vol. 4 No.1 2017.

Abu Shariah, Mohammad A. M. and Others, "Phonetically Rich and Balanced Text and Speech Corpora," Lang Research \& Evaluation, Vol.46,2012,601-634.

Abbâs al-Sûsah, al- 'Arabiyyah al-fushha al-Mu'ashirah, (Kairo : Dâr Garîb, 2002).

Andangdjaya, Hartojo, Puisi Arab Modern (Jakarta : Pustaka Jaya, 1983)

Boudelaa, Sami. dan William D Marslen-Wilson, "Aralex: A Lexical Database For Modern Standard Arabic," Behavior Research Methods, Vol.42,No2, 2010, 481-487

Boullata, Issa J." Midlle East Studies Association of North America (MESA)," Review of Middle East Studies, Vol.48, No.1/2,2014,116117,http://www.Jstor.Org/Stable/2433136, accesed:21-01-2016,48 UTC.

Dardiri, Taufiq A. Perkembangan Puisi Arab Modern (Adabiyat: Vol. X, No. 2 Desember 2011)

Ghania Droua Hamdani and Others, "Speaker Independent as For Modern Standard Arabic: Effect of Regional Accents," International Journal of Speech Technology, Vol 15 (2012),487-493

Haywood, John A. Modern Arabic Literature (London : Lund Humpries, 1971)

A. Mahfoud And Friends, Introduction To The Special Issue A Literacy In Arabic, "Article Reading ad Writing, Vol.24, No.9, 2011,1011-1018

Moeliono, Anton M. Perkembangan dan Pembinaan Bahasa: Rancagan dan Alternatif di dalam Perencaan Bahasa (Jakarta: Djambatan,1985)

Nasir, Amin. Bahasa Arab Era Klasik dan Modern (Tinjauan Pembelajaran Teoritis), Arabiya Vol. 6 No.1 Januari - Juni 2014 
Parera, J.D. Teori Semantik (Jakarta: Erlangga, 2004).

Robin, Christian Julien. "The Development of Arabic As A Written Introduction Language Types", Proceedings of The Seminar For Arabian of Arabic As A Written Language". Papers From The Special Session of The Seminar For Arabian Studies Hold on 24 July (2010),p1-3 Published by: Archaeopress Stable URL: htt://www.Jstor.Org/Stable/41224040

Stephan, Dahne. “Qur'anic Wording in Political Speeches in Classical Arabic Literature”, Journal of Qur'anic Studies, Vol.3, No.2, 2001, 1-13

https://wirsablog.wordpress.com/2012/09/15/bahasa-arab-modern-2/ Diakses 23 Maret 2018. Pukul 14.30 WIB. 